2008

\title{
Business Ethics Resources on the Internet
}

Scott A. Yetmar

Cleveland State University, s.yetmar@csuohio.edu

Follow this and additional works at: https://engagedscholarship.csuohio.edu/bus_facpub

Part of the Business Law, Public Responsibility, and Ethics Commons

How does access to this work benefit you? Let us know!

Publisher's Statement

The final publication is available at Springer via http://dx.doi.org/10.1007/s10551-007-9420-6.

\section{Original Published Citation}

Yetmar, S. A. (2008). Business Ethics Resources on the Internet. Journal of Business Ethics, 80(2), pp. 281-288.

This Article is brought to you for free and open access by the Monte Ahuja College of Business at EngagedScholarship@CSU. It has been accepted for inclusion in Business Faculty Publications by an authorized administrator of EngagedScholarship@CSU. For more information, please contact library.es@csuohio.edu. 


\section{Business Ethics Resources on the Internet}

Scott Andrew Yetmar

\begin{abstract}
There are an abundance of business ethics resources on the Internet. This paper details Internet resources with the following categories: Ethics Associations and Institutes, Ethics Journals, University Ethics Centers, Business Professions' Code of Conduct, Business Codes of Conduct, and Ethics Cases.
\end{abstract}

KEY WORDS: associations, cases, centers, codes of conduct, ethics resources, journals, institutes, Internet, web addresses, World Wide Web

\section{Introduction}

The following websites are useful for researchers in the area of business ethics. An exhaustive search was made using the Google and Yahoo directories. Each website was examined in detail for its worthiness. This is not to say that the following is all encompassing. There may be other valuable websites that have been accidentally overlooked. In addition, all the websites do not have the same value.

The following categories were used to organize the websites: Ethics Associations and Institutes, Ethics Journals, University Ethics Centers (United States and International), Business Professions' Code of Conduct, Business Codes of Conduct, and Ethics Cases (mostly free). All websites were accessible as of April 2007.

\section{Ethics Associations and Institutes}

The American Philosophical Association http:// www.apa.udel.edu/apa/index.html

The Aspen Institute http://www.aspeninstitute. org/

Association for Moral Education http:// www.amenetwork.org/
Association for Practical and Professional Ethics http://www.indiana.edu/ appe/

Australian Association for Professional and Applied Ethics http://www.arts.unsw.edu.au/ aapae/

BizEthics http://www.bizethics.org/

Business and Human Rights Resource Centre http://www.business-humanrights.org/

Business and Community http://www.bitc.org.uk/

Business Ethics - Canada http://www.businessethics.ca/

Business Ethics Center of Jerusalem http://www. besr.org/

Business in the Community http://www.bitc. org.uk/

Business Roundtable Institute for Corporate Ethics http://www.darden.virginia.edu/corporate-ethics/

Business for Social Responsibility http://www. bsr.org/

Canadian Business for Social Responsibility http:// www.cbsr.bc.ca/

Canadian Centre for Ethics in Public Affairs http://www.ccepa.ca/

Canadian Centre for Ethics \& Public Policy http://www.ethicscentre.ca/EN/index.cfm

The Canadian Society for the Study of Practical Ethics http://www.csspe.ca/

Caux Round Table http://www.cauxroundtable.org/index.html

Center for Business Ethics and Corporate Governance http://www.ethicsrussia.org/

Center for Ethical Business Cultures http:// www.cebcglobal.org/

Center for Ethics, Capital Markets, and Political Economy http://www3.iath.virginia.edu/cecmpe/

Center for Professional Responsibility of the American Bar Association http://www.abanet.org/ cpr/ 
Character Counts http://www.charactercounts. org/

Computer Ethics Institute http://www.brookings. edu/its/cei/default.htm

The Conference Board http://www.conferenceboard.org/knowledge/ethics.cfm

Corporate Ethics Management Council http:// www.conferenceboard.ca/GCSR/networks/cem.asp

Corporate Governance http://www.corpgov. net/

Corporate Responsibility Officer http://www. thecro.com/

Corporate Social Responsibility http://www. eldis.org/csr/

Council for Ethical Leadership http://www.businessethics.org/

Council of Ethical Organizations http://www. corporateethics.com/

Defense Industry Initiative on Business Ethics and Conduct http://www.dii.org/

e-Center for Business http://www.e-businessethics.com/

Ethical Impact http://www.ethicalimpact.com/

Ethics and Compliance Officer Association http://www.theecoa.org/

Ethics and Public Policy Center http://eppc.org/

Ethicscan Canada, Ltd. http://www.ethicscan.ca/

Ethics Institute of South Africa http://www.ethicsa.org.za/

Ethics Officer Association http://www.eoa.org

Ethics Practitioners' Association of Canada http://www.epac-apec.ca/

Ethics Resource Center http://www.ethics.org/

European Baha'i Business Forum http:// www.ebbf.org/

European Business Ethics Network - Belgium http://www.eben-net.org/index.htm

European Business Ethics Network - United Kingdom http://www.ebenuk.org/

Hong Kong Ethics Development Centre http:// www.icac.org.hk/hkedc/eng/main2.asp

Institute for Business Technology Ethics http:// www.ethix.org

The Institute for Global Ethics http://www. globalethics.org/index.htm

The Institute of Business Ethics http://www. ibe.org.uk/
Institute of Social and Ethical Accountability http://www.accountability21.net/

International Association for Business and Society http://www.iabs.net/

International Business Ethics Institute http:// www.business-ethics.org/

International Institute for Public Ethics http:// www.iipe.org/

International Society for Business, Economics, and Ethics http://www.isbee.org/

Jewish Association for Business Ethics http:// www.jabe.org/

Josephson Institute of Ethics http://www.josephsoninstitute.org/

National Ethics Bureau http://www.ethicscheck.com/

National Institute of Ethics http://www.ethicsinstitute.com/

National Whistleblower Center http:// www.whistleblowers.org/

Organisation for Economic Co-operation and Development http://www.oecd.org/

Professional Ethics - The Canadian Resource for Professional Ethics http://www.professionalethics.ca/

Public Affairs Council http://www.pac.org/public/ethics.shtml

The Society for Ethics http://www-rohan.sdsu. $\mathrm{edu} /$ faculty/corlett/se.html

Society of Corporate Compliance and Ethics http://www.corporatecompliance.org/

Society for Applied Philosophy http://www. appliedphil.org/index.shtml

Society for Business Ethics http://www.societyforbusinessethics.org/

St. James Ethics Centre - Australia http:// www.ethics.org.au/

Studies in Moral Development and Education http://tigger.uic.edu/ lnucci/MoralEd/index.html

The Texas Center for Legal Ethics and Professionalism http://www.txethics.org/

Transparency International http://www.transparency.org/

United States Office of Government Ethics http://www.usoge.gov/home.html

Workplace Fairness http://www.workplacefairness. org/ 


\section{Ethics Journals}

Business and Society http://www.sagepub.com/ journalsProdDesc.nav?prodId=Journal200878

Business and Society Review http://www.bentley. edu/cbe/research/bs_review.cfm

Business Ethics: A European Review http:// www.blackwellpublishing.com/journals/beer/

Business Ethics Quarterly http://www.society forbusinessethics.org/beq.htm

Business and Professional Ethics Journal: A Multidisciplinary Approach http://www.ethics.ufl.edu/ BPEJ/

Electronic Journal of Business Ethics and Organization Studies http://ejbo.jyu.fi/index.cgi?page=cover

Employee Responsibilities and Rights Journal http://www.springerlink.com/content/1573-3378/

Ethical Perspectives: Journal of the European Ethics Network http://www.ethical-perspectives. be/index.php

Ethical Theory and Moral Practice http:// www.springer.com/east/home?SGWID $=5-102-70$ $35553761-0 \&$ changeHeader $=$ true $\&$ referer $=w w w$. wkap.nl\&SHORTCUT=www.springer.com/prod/ j/1386-2820

Ethics \& Behavior http://www.erlbaum.com/ ME2/default.asp

Ethics \& Critical Thinking Quarterly Journal http://www.franklinpublishing.net/ethicscritical thinking.html

Ethics and Information Technology http://www. springerlink.com/content/1572-8439/

ETHICS: An International Journal of Social Political and Legal Philosophy http://www.journals. uchicago.edu/ET/home.html http://www.journals. uchicago.edu/ET/journal/available.html

Ethikos http://ethikosjournal.com/index.htm

The Georgetown Journal of Legal Ethics http:// www.law.georgetown.edu/journals/ethics/

Global Virtue Ethics Review http://www.spaef.com/GVER_PUB/index.html

Goodbusiness - An Online Journal http://robinson.gsu.edu/ethics/publications/index.html

International Business Ethics Review http:// www.business-ethics.org/iberpub.asp

International Journal of Value-Based Management http://www.springerlink.com/content/1572-8528/
International Journal of Applied Philosophy

http://www.nlx.com/Journals/ija.htm http:// www.pdcnet.org/ijap.html http://www.blackwell publishing.com/aims.asp? $\mathrm{ref}=0264-3758 \&$ site $=1$

International Review of Information Ethics

http://www.i-r-i-e.net/

Journal of Accounting, Ethics \& Public Policy http://www.angelfire.com/nj/dumontinstitute/ jaepp.html

Journal of Business Ethics

http://www.springer.com/west/home/philosophy?SGWID=4-40385-70-35739432-0 http://www. springerlink.com/content/1573-0697/ http://www. kluweronline.com/issn/0167-4544

http://www.editorialmanager.com/busi/ http:// www.springer.com/east/home/business/journals? SGWID=5-40528-70-35739432-0

Journal of Business Ethics Education http:// www.senatehall.com/journals.php?journal $=5$

Journal of Corporate Citizenship http://www. greenleaf-publishing.com/default.asp? ContentID $=7$

The Journal of Ethics

http://www.springerlink.com/content/15728609/

http://www.springer.com/west/home/philosophy? SGWID=4-40385-70-35621737-0

Journal of Global Ethics http://www.tandf. co.uk/journals/titles/17449626.asp

Journal of Information Ethics http://icie.zkm.de/ publications/journals/ie

Journal of Legal, Ethical and Regulatory Issues http://www.alliedacademies.org/UI/Journals/jleri. aspx

Journal of Power and Ethics: An Interdisciplinary Review http://www.spaef.com/JPE_PUB/index. html

New Academy Review: The International Journal of Corporate Social Responsibility, Sustainability, Leadership and Ethics http://www.newacademy-review.com/

Notre Dame Journal of Law, Ethics, \& Public Policy http://www.nd.edu/ ndjlepp/

Online Journal of Ethics

http://www.stthom.edu/academics/centers/ cbes/onlinejournals.html http://www.stthom.edu/ cbes/onlinejournals.html

Organizational Ethics: Healthcare, Business, and Policy http://www.organizationalethics.com/ 
Philosophy \& Public Policy Quarterly http:// www.puaf.umd.edu/IPPP/quarterly.html

Philosophy of Management http://www.managementphilosophers.com/

Professional Ethics: A Multidisciplinary Approach http://www.ethics.ufl.edu/PEJ/index.html

Research on Professional Responsibility and Ethics in Accounting http://www.bus.iastate.edu/cjeffrey/journal.asp

\section{Ethics Magazines/Newsletters}

Accountability http://www.accountability21.net/ resources $/$ default.asp?pageid $=76$

BizEthics Buzz http://www.business-ethics.com/ BizEthicsBuzz.htm

Corporate Ethics Monitor http://www.ethicscan.ca/products_services/education/corporate_ethics_monitor/index.html

E-Newsletter http://www.icac.org.hk/hkedc/ eng/enews.htm

Ethical Corporation Magazine http://www.ethicalcorp.com/

Ethics Matters Magazine http://www.bentley.edu/cbe/research/ethics_matters_magaz.cfm

Ethics Newsline http://www.globalethics.org/ newsline/members/index.tmpl

Ethical Performance - The Independent Global Newsletter for Socially Responsible Businesses http://www.ethicalperformance.com/

Living Ethics http://www.ethics.org.au/aboutethics/ethics-centre-articles/living-ethics-newsletter/index.html

Society for Business Ethics http://www.societyforbusinessethics.org/newsletter.htm

\section{University Ethics Centers - United States}

Applied Ethics Institute - St. Petersburg College http://appliedethicsinstitute.org/

Beard Center for Leadership in Ethics - Duquesne University http://www.bus.duq.edu/Beard/

The Blue Cross and Blue Shield of Florida Center for Ethics, Public Policy \& the Professions University of North Florida http://www.unf.edu/ $\mathrm{dept/ceppp/}$
Business Ethics Institute - Georgetown University http://faculty.msb.edu/prog/gbei/

Business Ethics and Society - University of Nebraska http://www.cba.unl.edu/outreach/BusEthSoc/

The Carol and Lawrence Zicklin Center for Business Ethics Research - The Wharton School http://www.zicklincenter.org/

Cary M. Maguire Center for Ethics and Public Responsibility - Southern Methodist University http://www.smu.edu/ethics_center/

Center for Applied Christian Ethics - Wheaton College http://www.wheaton.edu/CACE/

Center for Applied Philosophy and Ethics in the Professions - University of Florida http://www. ethics.ufl.edu/

Center for the Advancement of Applied Ethics and Political Philosophy - Carnegie Mellon University http://caae.phil.cmu.edu/caae

Center for Business Ethics - Bentley College http://www.bentley.edu/cbe/

Center for Business and Society - University of Colorado http://leeds.colorado.edu/businessandsociety/

Center for Corporate Citizenship - Boston College http://www.bcccc.net/

Center for the Study of Ethics in the Professions Illinois Institute of Technology http://www.iit.edu/ departments/csep/

Center for Ethical Business Cultures - St. Thomas University of Minnesota http://www.cebcglobal.org/

Center for Ethics - Emory University http:// www.ethics.emory.edu/

Center for Ethics - University of Montanta http://www2.umt.edu/ethics/

Center for Ethics and Business - Loyola Marymount University in Los Angeles http://www. lmu.edu/Page20711.aspx

Center for Ethics, Capital Markets and Political Economy - University of Virginia http://www3. iath.virginia.edu/cecmpe/iiindex.html

Center for Ethics Education - Fordham University http://www.fordhamethics.org/

Center for Ethics and Leadership - St. Edward's University http://www.stedwards.edu/ethics/

Center for Ethics and Public Service - University of Miami http://www.law.miami.edu/ceps/ 
Center for Ethics and Religious Values in Business - University of Notre Dame http://www.nd. edu/ ethics/

Center for Ethics and Social Justice - Loyola University, Chicago http://www.luc.edu/ethics/

Center for Professional Ethics - Case Western Reserve University http://www.case.edu/groups/ cpe/cpe.html

Center for Professional and Applied Ethics University of North Carolina at Charlotte http:// www.coas.uncc.edu/ethics/

Center for the Study of Ethics \& Human Values Washington University in St. Louis http://human values.wustl.edu/

Center for the Study of Ethics in Society Western Michigan University http://www.wmich. edu/ethics/

Center for the Study of Ethics in the Professions Illinois Institute of Technology http://ethics.iit.edu/

E-businessethics Center - Colorado State University http://www.e-businessethics.com/

Edmond J. Safra Foundation Center for Ethics Harvard University http://www.ethics.harvard.edu/

Emerson Center for Business Ethics - St. Louis University http://business.slu.edu/centers/Emerson_ Center/index.html

Ethics - Graduate School Programs http:// www.gradschools.com/listings/menus/ethics_menu.html

Hoffberger Center for Professional Ethics - University of Baltimore http://www.ubalt.edu/hoffberger/

Institute of Ethics - Gonzaga University http:// www.gonzagaethics.com/

Institute for Applied and Professional Ethics Ohio University http://freud.citl.ohiou.edu/ethics/

Institute for Business Integrity - Wright State University http://www.wright.edu/business/ibi/

Institute for Business and Professional Ethics DePaul University http://commerce.depaul.edu/ ethics/

Institute for Philosophy \& Public Policy - University of Maryland http://www.puaf.umd.edu/IPPP/

Institute for Social Responsibility, Ethics and Education - San Jose State University http:// www.sjsu.edu/depts/social_resp/social_resp.html

Institute for the Study of Applied and Professional Ethics - Dartmouth College http://www. dartmouth.edu/ ethics/index.html
Institute for the Study of Capitalism and Morality - Wheeling Jesuit University http://www.wju.edu/ academics/bus/iscm/

International Center for Ethics in Business University of Kansas http://www.business.ku.edu/ iceb/

International Center for Ethics, Justice and Public Life - Brandeis University http://www.brandeis.edu/ethics/

The Jackson Family Center for Ethics \& Values Coastal Carolina University http://www.coastal.e$\mathrm{du} / \mathrm{jacksoncenter/}$

Joan and David Lincoln Center for Applied Ethics - Arizona State University http://www.asu.edu/ clas/lincolncenter/

Kegley Institute of Ethics - California State University of Bakersfield http://www.cs.csubak.edu/ donna/kie/

The Kenan Institute for Ethics - Duke University http://kenan.ethics.duke.edu/

The Kennedy Institute of Ethics - Georgetown University http://kennedyinstitute.georgetown. edu/index.htm

Markkula Center for Applied Ethics - Santa Clara University http://www.scu.edu/SCU/Centers/ Ethics/homepage.shtml

Olsson Center for Applied Ethics - University of Virginia http://www.darden.virginia.edu/html/ area.aspx?styleid $=3 \&$ area $=$ olsson

Pacific Institute for Ethics \& Social Policy Pacific University http://www.pacificu.edu/ institute/

Pedro Arrupe Center for Business Ethics - Saint Joseph's University http://www.sju.edu/arrupe/

Poynter Center for the Study of Ethics and American Institutions - University of Indiana http://poynter.indiana.edu/index.shtml

Prudential Business Ethics Center - Rutgers University http://www.pruethics.rutgers.edu/

Robert J. Rutland Institute for Ethics - Clemson University http://www.clemson.edu/caah/rutland/

The Siegel Institute for Leadership, Ethics, and Character - Kennesaw State University http://siegelinstitute.org/

The Southern Institute for Business and Professional Ethics - Georgia State University http:// robinson.gsu.edu/ethics/index.html

Stanford Center on Ethics - Stanford University http://ethics.stanford.edu/ 
The Wharton Ethics Program - University of Pennsylvania http://ethics.wharton.upenn.edu/

Woodstock Theological Center - Georgetown University http://woodstock.georgetown. edu/

\section{University Ethics Centers - International}

Australian Association for Professional and Applied Ethics - University of New South Wales http:// www.arts.unsw.edu.au/aapae/

Cardiff Centre for Ethics Law \& Society http:// www.ccels.cardiff.ac.uk/

Centre for Applied Ethics - Hong Kong Baptist University http://cae.hkbu.edu.hk/

Centre for Business and Professional Ethics University of Leeds, Britain http://www.cbpe. leeds.ac.uk/

Centre for Business and Professional Ethics University of Pretoria, South Africa http:// www.gsm.up.ac.za/center.htm

Centre for Business and Public Sector Ethics Cambridge, UK http://www.ethicscentre.org/welcome. shtml

Centre for Business Relationships, Accountability, Sustainability and Society - Cardiff University, UK http://www.brass.cf.ac.uk/

Clarkson Centre for Business Ethics and Board Effectiveness - University of Toronto - Rotman http://www.rotman.utoronto.ca/CCBE/

The European Institute for Business Ethics, the Netherlands (Nyenrode Business Universiteit) http://www.nyenrode.nl/centers/eibe/index. cfm

Global Ethics - University of Birmingham, United Kingdom http://www.globalethics.bham. ac.uk/

International Forum on Management, Ethics \& Spirituality - HEC Montreal, Canada http://neumann.hec.ca/fimes/html/en/index 2.htm

Unilever Ethics Centre - University of Natal, South Africa http://www.ethics.unp.ac.za/

W. Maurice Young Centre for Applied Ethics University of British Columbia http://www.ethics.ubc.ca/

\section{Business Professions' Code of Conduct}

American Bar Association's Model Code of Professional Competency

http://www.abanet.org/cpr/mrpc/mcpr.pdf http://www.abanet.org/cpr/mrpc/home.html

American Institute of CPAs' Code of Professional Conduct http://www.aicpa.org/about/code/index. htm

American Institute of CPAs' Statements on Standards for Tax Services http://www.aicpa.org/ download/tax/SSTSfinal.pdf

American Marketing Association's Code of Ethics http://www.marketingpower.com/content21013.php

The Association for Information Management's Code of Ethics http://www.arma.org/about/overview/ethics.cfm

Chartered Financial Analyst - Finance Code of Ethics http://www.cfainstitute.org/aboutus/ conduct/

Financial Executives International's Code of Ethics http://www2.fei.org/about/ethics.cfm?

Financial Planning Association's Code of Ethics http://www.fpanet.org/member/about/principles/ Ethics.cfm

Institute of Internal Auditors http://www.theiia. org/guidance/standards-and-practices/professionalpractices-framework/code-of-ethics/code-of-ethics-english/

Institute of Management Accountants' Statement of Ethical Professional Practice http://www.imanet.org/about_ethics_statement.asp

Institute for the Management of Information Systems' Code of Ethics http://www.imis.org.uk/ about/codeofethics/code_ethics.pdf

The Institute of Chartered Accountants in England \& Wales' Code of Ethics

http://www.icaew.co.uk/index.cfm?route $=135844 \mathrm{http}: / /$ www.icaew.co.uk/index.cfm?route $=125788 \quad \mathrm{http}: / / \mathrm{www} \cdot \mathrm{icaew} \cdot \mathrm{co} \cdot \mathrm{uk} / \mathrm{index}$. cfm?route $=127641$

International Federation of Accountants' Code of Ethics http://www.ifac.org/Guidance/index.php

Legal Associations - US, Canada, UK - Code of Ethics http://www.law-lib.utoronto.ca/resources/ orgs/legassn.htm 
National Association of Insurance \& Financial Advisors' Code of Ethics http://www.naifa.org/ about/ethics.cfm

United States Treasury Department's Circular 230 http://www.irs.gov/pub/irs-pdf/pcir230.pdf

\section{Business Codes of Conduct}

Associations' Code of Conduct http://www.grad. umn.edu/Ethics/codes.html

BELL: The Business Ethics Links Library http:// libnet.colorado.edu/Bell/

Business Ethics Codes http://www.web-miner. com/busethics.htm\#codes

Code of Online Business Practices http:// www.bbbonline.org/reliability/code/code.asp

Companies Code of Conduct - UK http:// www.ibe.org.uk/examples.html

Corporate Codes of Ethics http://www. web-miner.com/busethics.htm\#codes

Codes of Conduct http://www.codesofconduct.org/

Codes of Ethics and Conduct http://onlineethics.org/codes/

Codes of Professional Ethics http://www.grad.niu.edu/orc/pdf/ethics.pdf

Computer Society Codes from Around the World http://courses.cs.vt.edu/ cs3604/lib/World Codes/WorldCodes.html

Ethics Codes \& Practice Guidelines for Assessment, Therapy, Counseling, \& Forensic Practice http://kspope.com/ethcodes/index.php

Ethicsweb - Canada http://www.ethicsweb.ca/ resources/business/codes.html

Illinois Institute of Technology http://ethics. iit.edu/codes/

New Ethic http://mysite.verizon.net/lestershepard/ ethiclinks.html\#Professional

North Carolina State University http://www. fis.ncsu.edu/grad/ethics/ethicnet.htm

Professional Codes of Conduct http://www. advocateweb.org/hope/codesofethics.asp

Profession's Codes of Conduct http://www. ethicsweb.ca/resources/professional/codes-of-ethics. html

University of Minnesota http://www1.umn.edu/ humanrts/links/allcodes.html
Virginia Tech http://courses.cs.vt.edu/ cs3604/ lib/WorldCodes/WorldCodes.html

Wharton Ethics Program

http://ethics.wharton.upenn.edu/Links.htm\#codes http://ethics.wharton.upenn.edu/Links.htm\# scandals

\section{Discussion Forums \& Message Boards}

Business Ethics Forum http://www.managementlogs.com/business_ethics.html

Discussion of Ethics on the Net http://frank. mtsu.edu/ jpurcell/Ethics/ethics.html

Ethics Forum http://www.ethics.org.au/ethics_ forum/default.asp

Markkula Center for Applied Ethics http://www. scu.edu/ethics/boards/thread_main.cfm?family= business

\section{Ethics Cases}

American Institute of CPAs

http://fmcenter.aicpa.org/Resources/Traditional/ Ethics+and+Fraud +in+Business+Cases + and +Commentary.htm http://ceae.aicpa.org/Resources/Education+and+Curriculum+Development/Classroom+ Materials/

American Legal Ethics Library - Cornell University http://www.law.cornell.edu/ethics/

Arthur Andersen Case Studies in Business Ethics http://ba.gsia.cmu.edu/ethics/AA/arthurandersen. htm

The Asian Business Case Centre http:// www.asiacase.com/

Babson College Cases http://roger.babson.edu/ ethics/

Business 2000 Case Studies http://www.business2000.ie/html/case_studies/index.htm

Business Case Journal http://www.sfcr.org/bcj/ bcj.htm

Business Case Studies http://www.businesscases. org/newInterface/index.phtml

Business Ethics Cases http://www.web-miner. com/busethics.htm\#cases

Business Ethics - CA Cases

http://www.businessethics.ca/cases/wb-env1. html http://www.businessethics.ca/cases/pollut- 
ersdilemma1.html http://www.businessethics.ca/ cases/ehealth-and-cgt.html

Business Roundtable Institute for Corporate Ethics http://www.darden.virginia.edu/corporate-ethics/ cases.htm

The Case Place http://www.caseplace.org/

Case Research Journal http://www.nacra.net/crj/

The Cheating Culture http://www.cheatingculture.com/

Company Case Studies http://www.thetimes 100.co.uk/company_list.php

Creighton University http://cobacourses.creighton.edu/ecomethics/

Darden Business Publishing http://store.darden. virginia.edu/ecustomer_enu/start.swe?SWECmd= Start

Dilemma: Right vs. Right http://www.globalethics.org/resources/dilemmas.htm

$\mathrm{ECCH}$ - The Case for Learning http://www. ecch.com/

e-Center for Business Ethics http://e-business ethics.com/case.htm

Ethics Case Studies - University of San Diego http://ethics.sandiego.edu/resources/cases/Home Overview.asp

Financial Scandals http://www.ex.ac.uk/ $\sim$ RDavies/arian/scandals/

Forensic Accounting Case Material - AICPA http://ceae.aicpa.org/Resources/Education+and+ Curriculum+Development/Classroom+Materials/ Forensic + Accounting + Case + Material + and + Role + Play+Exercise + for + Students.htm

Fraud Information Centers http://ethics.wharton. upenn.edu/Links.htm\#scandals

Harvard Business Cases http://harvardbusinessonline.hbsp.harvard.edu/b01/en/cases/cases_home. jhtml
ICFAI Center for Management Research http:// icmr.icfai.org/casestudies/icmr_case_studies.htm

Illinois CPA Society http://www.icpas.org/ icpas/consumer/ethics-casestudies.asp

Industry Scenarios http://onlineethics.org/ projects/index.html\#industry

Institute of Management Accountants Case e-Journal http://www.imanet.org/membership_ helping_educator_instructor_ejournal.asp

Ivey Publishing http://cases.ivey.uwo.ca/cases/ Pages/home.aspx

Journal of Accounting Case Research http:// www.captus.com/information/catalogue/

book.asp?Book + Number $=854$

The Management Case Study Journal http:// www.ojs.unisa.edu.au/journals/index.php/MCSJ

Markkula Center for Applied Ethics

http://www.scu.edu/ethics/practicing/focusareas/cases.cfm http://www.scu.edu/ethics/practicing/ focusareas $/$ cases.cfm?fam $=$ BUSI

McGraw Hill Publishing http://www.primisonline.com/cgi-bin/POL_cases.cgi

South-Western Publishing http://casenet.thomsonlearning.com/casenet_global_fr.html

Stanford University http://gsbapps.stanford.edu/ cases/

Utah Valley State College http://www.uvsc.edu/ ethics/curriculum/business/

Scott Andrew Yetmar

College of Business Administration,

Cleveland State University,

2121 Euclid Avenue, Cleveland, OH, 44115, U.S.A. E-mail:s.yetmar@csuohio.edu 